\title{
ПРАВОВЕ РЕГУЛЮВАННЯ СОЦІАЛЬНОӤ СФЕРИ: СУЧАСНИЙ СТАН ТА НАПРЯМИ УДОСКОНАЛЕННЯ
}

\author{
КАПІТАН Ольга Іторівна - аспірант кафедри Львівського державного \\ університету внутрішніх справ
}

DOI:10.32782/NP.2019.4.9

УДК 342.9

\begin{abstract}
В статье исследуются правовъе аспектьи публичного регулирования социальной сберы. Дается теоретический анализ правового регулирования административно-правовых отношений, складъввающихся в сбере управления отраслями сочиальной сберьи. Определенъ тендениии ребормирования административного права в связи с переориентаиией деятельности государства на нужды лица, вылвижение его прав, свобод и законнъгх интересов на передний край административно-правового регулирования.

Ключевые слова: сочиальное государство, сочиальная сбера, государственное управление, государственное регулирование, публичное регулирование, административно-правовое регулирование.
\end{abstract}

\section{Постановка проблеми}

Стратегічним напрямом зовнішньої політики України є інтеграція до Европейського Союзу, що передбачає наближення до політичних, юридичних, економічних та соціально-культурних стандартів EС. Процес реформування дозволить підвищити рівень життя населення, шляхом досягнення соціальної справедливості. Однак, на сьогодні в Україні існують проблеми соціального, політичного та економічного характеру, від результативності вирішення яких залежить успішність курсу на євроінтеграцію та подальший розвиток країни в цілому.

Реформування саме соціальної сфери є пріоритетним. Система соціального захисту та соціальних гарантій України потребує удосконалення, особливо в період глобалізації економічного, політичного та суспільного життя.

Прийняття Конституції України стало початком якісно нового етапу в розвитку суспільства й держави, правової системи України, необхідною базою іiі реформування. Однією із складових реформування правової системи держави є проведення адміністративно-правової реформи, що потребує послідовної реалізації як національних законів, так і вимог міжнародноправових актів. Упродовж останніх років здійснювалися деякі заходи щодо виконання окремих положень концепції, проте іiі впровадження є повільним та суперечливим. Виникла потреба в науковому моніторингу адміністративної реформи в Україні, виявленні найбільш проблемних питань функціонування управління у соціальній сфері. У даний час розвиток соціальної сфери та виконання покладених на неї функцій відбувається перш за все за рахунок бюджетного фінансування і механізму державного регулювання. В основі останнього лежить нормативно-правова база, що визначає правове положення органів, установ та посадових осіб у галузях соціальної сфери [1, с. 208].

Метою статті $\epsilon$ дослідження правових засад державного регулювання окремих галузей соціальної сфери. 


\section{Аналіз останніх досліджень}

Дослідження проблем соціального захисту населення представлено у працях провідних науковців: Качуренко Ю., Скуратівський В., Трощинський В., Ситник П., Борецька Н., Бригадін П., Бакиров В., Даниленко I., Кизилова К., Кузина І., Чечель А., Тарасенко Д., Куценко О. та інші. Вклад учених у вивченні актуальних питань функціонування соціальної сфери є дуже вагомим, але не слід недооцінювати необхідність розвитку та вивченню питань, які стосуються подальшого розвитку соціальної сфери на шляху євроінтеграційних процесів.

\section{Виклад основного матеріалу}

Прагнення України увійти в Европейську Співдружність країн та у Европейський Союз неможливе без створення системи правових, економічних, організаційних та інших заходів державних і недержавних установ та організацій, що впливатимуть та сприятимуть підтриманню соціальної стабільності в суспільстві, створенню умов для зростання добробуту населення, забезпечення належного рівня та якості життя населення. Реалізація соціальної політики стосовно будь-якої категорії громадян неможлива без здійснення їх соціального захисту, а соціальний захист - важлива складова соціальної політики та необхідний елемент функціонування держави в умовах ринкової економіки. Визначальним аспектом дослідження механізму правового регулювання соціальних суспільних відносин $є$ аналіз системи законодавства, тобто сукупності взаємопов'язаних нормативно-правових актів, що містять основні норми та приписи, які регламентують відносини у соціальній сфері [2, с. 247].

Серед структурних елементів правової системи важливе місце належить правовому регулюванню. У юридичній літературі попри різні підходи до його визначення сформувалось певне розуміння сутності правового регулювання. Термін «регулювання» походить від латинського слова «reguło» правило та означає впорядкування, приведення чогось у відповідність з чимось. Під правовим регулюванням більшість авторів розуміє сукупність прийомів та засобів юридичного впливу на поведінку суб'єктів суспільних відносин. Правове регулювання передбачає впорядкування, юридичне закріплення та охорону суспільних відносин шляхом застосування правових засобів [3, с. 11]. Сферою правового регулювання є ті суспільні відносини (економічні, політичні, культурні, національні, релігійні та ін.), які потребують правового впливу. Ці відносини становлять предмет правового регулювання, вони є вольовими відносинами, об'єктивно потребують впливу з боку держави та мають чітко визначений зміст. В економічній сфері - це відносини, пов'язані 3 формуванням ринкових взаємозв'язків, 3 розвитком різних форм власності, з виробництвом, розподілом матеріальних благ, 3 розвитком фермерського господарства.У політичній сфері - це правове закріплення плюралістичних форм та методів здійснення влади, формування демократичних інститутів. У соціальній сфері - це формування соціальної політики, спрямованої на задоволення інтересів конкретної людини в галузі освіти, охорони здоров'я, соціального забезпечення та інших сферах. Сьогодення вимагає вивчення та формування пріоритетних напрямків правового регулювання. Отже, сферою правового регулювання є різні види відносин, а саме: економічні, політичні, духовно-культурні, національні, релігійні тощо, які відрізняються своєю цілеспрямованістю, змістом та формою [3, с. 11].

Однією із найважливіших конституційних характеристик української держави iï характеристика як держави соціальної. Найважливішою особливістю такого типу держави є високий рівень соціальної безпеки і соціальної захищеності її громадян. Досягнення такого рівня можливе завдяки ефективної реалізації соціальної політики. У iï формуванні й здійсненні бере участь чимало суб'єктів, діяльність яких визначається конкретними соціальними інтересами й здійснюється на основі тієї або іншої нормативно - правової бази [4, с. 5]. Це - державні органи влади, органи місцевого самоврядування, недержавні організації, громадські об'єднання. Тобто, залежно від того, хто ініціює та встановлює ці взаємини та проводить відповідні заходи, розрізняють види 


\section{Адміністративне право}

соціальної політики: державна; регіональна; корпоративна. Основним суб'єктом реалізації соціальної політики в сучасному світі є держава, яка визначає загальні їі засади, мету, завдання, пріоритети, нормативно - правову базу й проводить безпосередню практичну роботу з ії реалізації. Державна соціальна політика - це дії держави в соціальній сфері, що переслідують певні цілі, співвіднесені з конкретно - історичними обставинами, підкріплені необхідними організаційними й пропагандистськими зусиллями, фінансовими ресурсами й розраховані на певні етапні соціальні результати [4, с. 5].

Соціальна сфера суспільства 6 складним багаторівневим комплексом, що має i змістовну, і функціональну, і організаційну структури, відображає систему соціальних відносин та їх носіїв, сукупність інтересів, потреб, очікувань людей. Усі елементи соціальної сфери тісно пов'язані між собою, а вона сама постійно взаємодіє з іншими сферами життедіяльності суспільства, є відкритою системою, що динамічно розвивається. Як зазначає Ю.Г. Горященко, соціальна сфера - це «каталізатор розвитку цивілізації, чинник формування духовно зрілої, компетентної, соціально активної людини, яка комфортно себе почуває в умовах будь-якої професійної діяльності» [5, с. 568]. Особливістю соціальної сфери є те, що вона формується під впливом відносин соціальних груп та індивідів, які мають різне соціально-економічне становище в суспільстві $[6$, с. $39 ; 7$, c. 185].

Для ефективного функціонування соціальної держави кількість державних витрат на соціальну сферу повинна визначитися об'єктивними потребами суспільства, гостротою його потреб, а заходи соціальної допомоги, через широкий спектр їі форм, повинні носити адресний характер.

Для соціальної політики України це означає активну роль держави в економіці, соціальний контроль, створення ефективної системи соціального захисту, дотримання прав людини, тобто посилення соціальної орієнтованості держави, важливим показником якої є обсяг та характер фінансування державою соціальних програм і

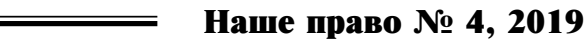

співвідношення статей видаткової частини держбюджету [8].

Однак у сучасному українському суспільстві, де соціальна солідарність між групами населення відсутня, а економічний ріст не набув сталого характеру, реальністю $\varepsilon$ iстотна соціальна диференціація та жорсткі бюджетні обмеження 3 фінансування соціальної сфери за залишковим принципом. У зв'язку із цим, можна говорити про формування стійкої тенденції до виникнення субсидіарної держави $з$ вузьким колом адресатів соціальних виплат із числа найбільш незабезпечених категорій громадян.

Соціальна політика є обов'язковим елементом діяльності суспільства й держави, iï найважливішу область, де конструюється бажаний стан соціальної сфери, що і виступає її основним об'єктом.

Держава в особі відповідних органів управління на загальнодержавному та регіональному рівнях на основі дії принципу соціальних гарантій відповідає за ріст рівня життя та соціальну облаштованість громадян. Отже, соціальна політика демонструє, як цілі та завдання, висунуті базовими соціальними інститутами, у конкретний період часу співвідносяться 3 існуючими в людей уявленнями про необхідний рівень їхньої соціальної забезпеченості. Виходячи з цього, О. Ю. Оболенський визначає соціальну політику як комплекс соціально-економічних заходів держави, підприємств, установ, організацій, спрямований на послаблення нерівності в розподілі доходів і майна, на захист населення від безробіття, підвищення цін, знецінення трудових заощаджень та ін. [9, с. 271].

Об'єкт соціальної політики - це те, на що вона спрямована. Ми погоджуємося 3 думкою Оксьома I.Г, що саме соціальна сфера є об'єктом соціальної політики [1, с. 210].

Враховуючи, що соціальна сфера охоплює широкий спектр суспільних відносин, проаналізуємо систему законодавства щодо розвитку їі провідних галузей.

Для конституційно-правого регулювання права громадян на охорону здоров'я в Україні на сучасному етапі характерна орієнтація на міжнародні стандарти 3 прав людини. В Україні право на охорону 
здоров'я, як у всіх розвинених країнах, закріплено в Конституції. Стаття 49 Конституції України серед іншого встановлює, що держава має створювати умови для ефективного і доступного всім громадянам медичного обслуговування, сприяти розвитку лікувальних закладів усіх форм власності, у державних і комунальних закладах охорони здоров'я медичну допомогу повинні надавати безоплатно [3]. Таким чином, Конституція України визначає загальні концептуальні підходи до регулювання відносин у галузі охорони здоров'я. Деталізація та конкретизація основних конституційних положень щодо нормативно-правового регулювання у галузі охорони здоров'я i механізмів їх реалізації знайшли своє відображення в законах України, постановах Верховної Ради, указах та розпорядженнях Президента України, постановах та розпорядженнях Кабінету Міністрів України, нормативних актах центральних органів виконавчої влади та міжнародних договорах України. У деяких випадках положення законодавчих актів України істотно відрізняються від близьких за формулюваннями положень міжнародних документів. Aле урегульовані правом суспільні відносини не обмежуються автоматичним виконанням владних приписів. Розвиток соціальних процесів, пов'язаних з охороною здоров'я, спонукає до критичного перегляду наявного правового масиву щодо регулювання відносин у галузі охорони здоров'я, якому має передувати усвідомлення його застарілості чи навіть непридатності, що формується на підставі трансформації потреб та інтересів, спричинених об'єктивним розвитком суспільства в контексті адаптації законодавства до вимог EC [2, с. 248].

Крім того, Основний Закон України встановлює, що основи соціального захисту, форми і види пенсійного забезпечення належать до виключного регулювання на підставі норм закону (ч. 1 ст. 92). Пріоритетність законодавчого регулювання відносин 3 питань соціального забезпечення є основоположним принципом у правотворчій діяльності держави. Проте реалізація цього принципу вимагає не тільки систематизації, а також, що важливо, кодифікації законо- давства про соціальне забезпечення, адже множинність законів 3 питань соціального забезпечення ускладнює їх належну реалізацію на практиці [10].

Враховуючи складність правового регулювання відносин 3 питань соціального забезпечення, очевидною є проблема проведення кодифікації не тільки законодавства про соціальне забезпечення, а, щонайменше, також про пенсійне забезпечення, права осіб з інвалідністю. Специфічність таких кодифікованих процесів має максимально відображати потреби та інтереси всіх членів суспільства, і вони мають бути суспільно-прийнятними, позаяк кожна людина у нашій державі впродовж свого життя виступає суб'єктом правових відносин 3 соціального забезпечення.

На основі проведеного дослідження чинного законодавства щодо соціального захисту пропонуємо такі заходи 3 його удосконалення:

- розробити і затвердити сучасну модель соціального захисту на основі прозорих, доступних і дієвих механізмів ії реалізації;

- визначити чіткий соціально-правовий статус окремих вразливих категорій населення;

- провести якісну суспільноприйнятну кодифікацію законодавства про соціальне забезпечення на основі поєднання інтересів особи, суспільства і держави;

- провести суспільноприйнятну кодифікацію законодавства про пенсійне забезпечення;

- запровадити дієвий громадський контроль і державний нагляд за дотриманням законодавства про соціальне забезпечення.

На шляху створення якісної нормативно-правової бази у сфері охорони здоров'я трапляється чимало перепон і труднощів. Так, наприклад, С. Стеценко серед них виділяе такі:

- недостатньо виражена державна політика у сфері охорони здоров'я, в тому числі їі законодавчого забезпечення;

- відсутність науково обгрунтованої стратегії законотворчої діяльності у сфері охорони здоров'я;

- низька законотворча активність суб'єктів законодавчої ініціативи; 


\section{Адміністративне право}

- складність проходження законопроєктів про охорону здоров'я у Верховній Раді України;

- незначна кількість спеціалістів, які б мали необхідний обсяг знань у сфері юриспруденції та медицини [11, с. 88];

- неконсолідованість діяльності представників правової і медичної науки;

- недостатне врахування міжнародно-правових стандартів у сфері охорони здоров'я і неефективне використання позитивного зарубіжного досвіду в регулювання охорони здоров'я;

- нечіткість правової бази у сфері охорони здоров'я, законодавчі колізії і проблеми, що виникають на практиці, коли норми різних актів, які регламентують тією чи іншою мірою охорону здоров'я, суперечать один одному;

- надмірна розпорошеність норм щодо охорони здоров'я по всьому українському законодавству [11, с. 88].

Слабка законодавча ініціатива і складність проходження законопроєктів у Верховній Раді - це два боки однієї проблеми. Незважаючи на те, що створення належної нормативно - правової бази охорони здоров'я передбачає динамічність правотворчого процесу, на практиці постійно гальмується прийняття законів, що регламентують ключові питання функціонування вітчизняної охорони здоров'я. Тому законопроєкти про охорону здоров'я, зокрема про загальнообов'язкове державне медичне страхування, про правовий статус пацієнтів, про фінансування охорони здоров'я тощо не один рік знаходяться на різних стадіях законотворчого процесу, так і не ставши частиною національної правової бази охорони здоров'я. При розробці власної нормативно - правової бази необхідно врахувати міжнародно-правові стандарти у сфері охорони здоров'я, досвід зарубіжних країн щодо медичного законодавства. Разом з тим, при законотворчій діяльності необхідно врахувати національні особливості, традиції і реалії. Вивчення міжнародно-правових стандартів і зарубіжного досвіду у цій сфері дасть можливість виділити перспективні напрямки для оновлення українського законодавства та ре- формування охорони здоров'я в цілому [2, c. 248].

На сучасному етані важливим питанням соціальної політики $\epsilon$ істотне оновлення законодавства, особливо в тих галузях соціальної сфери, які потребують якісного i системного реформування. Насамперед, це стосується соціального забезпечення, адже законодавство про соціальне забезпечення перебуває на етані становлення і на шляху його формування трапляється чимало проблемних питань. Серед них, наприклад,В. Мельник виділяє такі:

- невідповідність розвитку суспільства і держави;

- невідповідність потребам оптимальної моделі соціального забезпечення;

- незабезпечення доступності та недостатня дієвість права на соціальний захист та інших прав на соціальне забезпечення;

- наявність множинності законів 3 окремих питань соціального забезпечення;

- наявність розгалуженої системи актів законодавства, де домінуючою частиною залишається система підзаконним нормативних актів;

- високий ступінь диференціації правового регулювання, складність і суперечливість;

- відсутність якісного державного нагляду і громадського контролю [12, с. 260].

Разом 3 тим, законодавство про соціальне забезпечення виступає об'єктивним і закономірним виразом розвитку права на соціальний захист і забезпечення через вироблення конструктивних механізмів його реалізації, гарантування і правової охорони. Як відомо, Конституція України (ст. 46) передбачає, що громадяни мають право на соціальний захист, який включає право на забезпечення їх у разі повної, часткової або тимчасової втрати працездатності, втрати годувальника, безробіття з незалежних від них обставин, а також у старості та інших випадках, передбачених законом. Це право гарантується загальнообов'язковим державним соціальним страхуванням за рахунок страхових внесків громадян, підприємств, установ, організацій, а також бюджетних та інших джерел соціального забезпечення; створення мережі державних, комуналь- 
них, приватних закладів для догляду за непрацездатними. При цьому пенсії й інші види соціальних виплат та допомоги, які є основним джерелом існування, мають забезпечити рівень життя, не нижчий від прожиткового мінімуму, встановленого законом [11, с. $34 ; 2$, с. 249].

\section{Висновки}

Для вирішення системних проблем у соціальній сфері необхідно розробляти взаємопов'язані державні, регіональні та індивідуально орієнтовані програми людського розвитку, які б враховували об'єктивні умови людського розвитку в тих чи інших регіонах, а також специфічні потреби та проблеми їх мешканців, тобто використовувати програмно-цільовий механізм. Вдосконалення програмно-цільового механізму можливо шляхом розробки нового покоління соціальних індивідуально орієнтованих програм, спрямованих на вироблення ключових компетенцій людського розвитку. Таким чином, державі необхідно ставити та вирішувати наступні завдання:

1. Розробка компетентнісної структури (матриці) населення як управляючого знання у державній політиці людського розвитку.

2. Розробка пакету індивідуально орієнтованих програм ^юдського розвитку та методичних рекомендацій для територій по запуску програм із консолідованим бюджетом.

3. Запуск спеціальної програми національного (масового) тренінгу компетенцій для цільових груп.

4. Дослідження досвіду та розробка нових форм соціального партнерства під програми нового покоління в соціальній політиці [13, с. 112].

Безперечно, важливе значення, що є одним із пріоритетних напрямів євроінтеграції України $є$ «поступове наближення до права, стандартів та практики Европейського Союзу у сфері зайнятості, соціальної політики та рівних можливостей», що зазначено у положеннях Угоди про асоціацію між Україною, з одного боку, та Европейським Союзом, Европейським співтовари- ством 3 атомної енергії і їхніми державами-членами, 3 іншого. Інтеграція України у світовий економічний простір вимагає застосування міжнародних інструментів та стандартів у сфері соціально-трудових відносин, а також дотримання міжнародних вимог та зобов'язань, гармонізації національних економік та законодавства. У зв'язку з цим, наукового та прикладного опрацювання потребує питання визначення відповідності та адаптації національних соціально-трудових норм до міжнародних вимог. Впровадження міжнародних соціально-трудових стандартів в українську практику буде сприяти посиленню захисту прав громадян, а також розвитку національної соціальної політики в умовах європейської інтеграції [4, с. 6].

\section{Лiтература}

1. Оксьом I. Г. Публічне регулювання соціальної сфери: правовий аспект. Публічне право. 2016. № 3 (23). С. 208-217.

2. Оксьом I. Г. Правове регулювання соціальної сфери: сучасний стан та напрями удосконалення. Публічне право. 2015. № 4 (20). С. 246-253.

3. Тарахонич T.I. Ефективність правового регулювання (питання теорії). Часопис Киӥвсъкого університету права. 2010. № 2. C. 11-13.

4. Зайнятість, праця та соціальний захист населення: вітчизняний та зарубіжний досвід. За ред. к.е.н., професора Т. М. Кір'ян. К.: 2017. 245 с.

5. Розміщення продуктивних сил і регіональна економіка: [підручник] / [C. I. Дорогунцов, Т. А. Заяць, Ю. І. Пітюренко та ін.]; за заг. ред. С. І. Дорогунцова. К.: КНЕУ, 2005. 568 с.

6. Горященко Ю. Г. Проблеми розвитку соціальної сфери економічних регіонів України. Украӥна: аспекти праизі. 2011. № 1. C. 37-43.

7. Кузьменко С. Г. Державні та господарські механізми регулювання соціальної сфери суспільства. Науковий вісник Херсонсъкого державного університету. 2015. Вип. 3. Т. 1. C. 184-187.

8. Панченко М. Соціальна сфера і соціальна політика та їх співвідношення в ас- 


\section{Адміністративне право}

у статті досліджуються правові аспекти публічного регулювання сочіальної сфери. Дається теоретичний аналіз правового регулювання адміністративно-правових відносин, щзо складаються у сбері управління галузями сочіальної сфери. Визначено тенденцї ребормування адміністративного права у зв'язку з переорієнтацією діяльності держави на потреби особи, висунення ї̈ прав, свобод та законних інтересів на передній край адміністративно-правового регулювання.

Ключові слова: сочіальна держава, сочіальна сбера, державне управління, державне регулювання, публічне регулювання, адміністративно-правове регулювання.

пекті державного управління соціальною сферою [Електронний ресурс]. URL: http:// www.nbuv.gov.ua/old_jrn/Soc_Gum/Apdu_o/ 2009_1/R_5/Panchenko.pdf.

9. Державне управління та державна служба. Словник-довідник / УкладачО.Ю. Оболонський. К.: КНЕУ, 2005. 478 с.

10. Тищенко О. В. Право соціального забезпечення України: теоретичні та практичні проблеми формування розвитку галузі: монограбія. К.: ДП «Прінт Сервіс», 2014. C. 31 .

11. Стеценко С. Г., Стеценко В. Ю., Сенюта I. Я. Медичне право України: підручник /за заг. ред. д. ю. н., проф. С. Г. Стеценка. К.: Всеукраїнська асоціація видавців «Правова єдність», 2008. 507 с.

12. Мельник В. П. Законодавство про соціальне забезпечення: поняття, ознаки та напрями вдосконалення. Держава і право: зб. наук. праць. Серія Юридичні науки. Ін-т держави і права ім. В. М. Корецького НАН України. 2015. Вип. 67. К.: Вид-во «Юридична думка», 2015. С. 260.

\section{SUMMARY}

The article explores the legal aspects of public regulation of the social sphere. The theoretical analysis of legal regulation of administrative and legal relations, which are formed in the sphere of management of branches of social sphere, is given. The tendencies of reforming the administrative law in connection with the reorientation of the activity of the state to the needs of the individual, the promotion of his rights, freedoms and legal interests to the forefront of administrative and legal regulation are determined. The implementation of social policy in relation to any category of citizens is impossible without the implementation of their social protection, and social protection is an important component of social policy and a necessary element of the functioning of the state in a market economy.

It is emphasized that the strategic direction of Ukraine's foreign policy is integration with the European Union, which implies approximation to the political, legal, economic and socio-cultural standards of the $E U$. The reform process will increase the standard of living of the population by achieving social justice. However, to date, there are problems of a social, political and economic nature in Ukraine, the effectiveness of which depends on the success of the course on European integration and the further development of the country as a whole.

Reforming the social sphere is a priority. The system of social protection and social guarantees of Ukraine needs improvement, especially in the period of globalization of economic, political and social life.

Key words: social state, social sphere, public administration, state regulation, public regulation, administrative and legal regulation.

13. Поспєлова Т. В., Орлова Н. С. Програмно-цільовий механізм державного регулювання соціальної сфери. Державне управління. Наукові праці. 2017. Вип. 278. Т. 290. C. 108-113. 